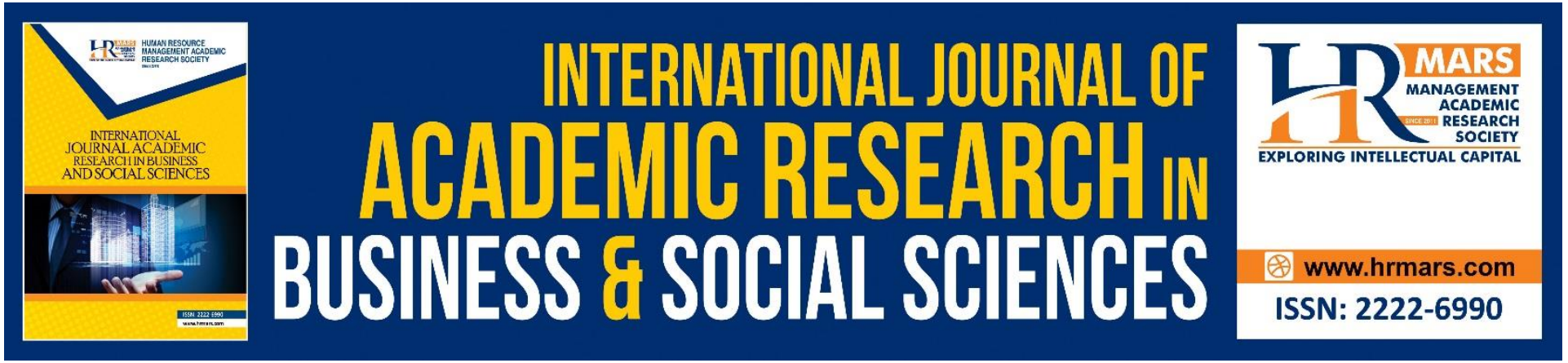

\title{
Analysis of Destination Image Factors on Tourism Satisfaction in Lake Kenyir, Terengganu
}

Emisham Embong, Mutia Sobihah Abdul Halim, Mohamad Muhaymein Ahmed Zawawi

To Link this Article: http://dx.doi.org/10.6007/IJARBSS/v11-i9/11000

DOI:10.6007/IJARBSS/v11-i9/11000

Received: 04 July 2021, Revised: 28 July 2021, Accepted: 18 August 2021

Published Online: 09 September 2021

In-Text Citation: (Embong et al., 2021)

To Cite this Article: Embong, E., Halim, M. S. A., \& Zawawi, M. M. A. (2021). Analysis of Destination Image Factors on Tourism Satisfaction in Lake Kenyir, Terengganu. International Journal of Academic Research in Business and Social Sciences, 11(9), 336-350.

Copyright: @ 2021 The Author(s)

Published by Human Resource Management Academic Research Society (www.hrmars.com)

This article is published under the Creative Commons Attribution (CC BY 4.0) license. Anyone may reproduce, distribute, translate and create derivative works of this article (for both commercial and non-commercial purposes), subject to full attribution to the original publication and authors. The full terms of this license may be seen at: http://creativecommons.org/licences/by/4.0/legalcode

Vol. 11, No. 9, 2021, Pg. 336 - 350

Full Terms \& Conditions of access and use can be found at http://hrmars.com/index.php/pages/detail/publication-ethics 


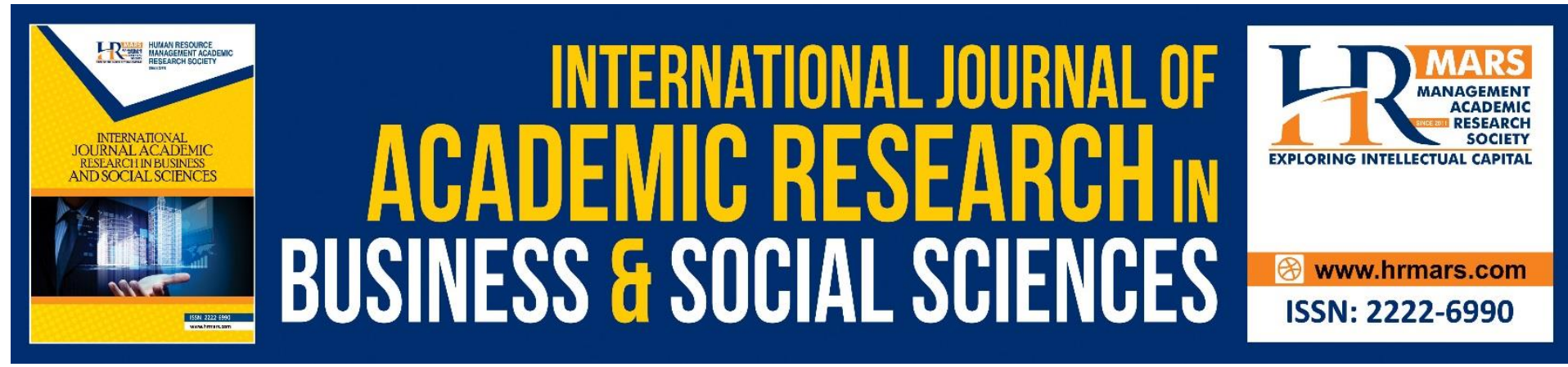

\title{
Analysis of Destination Image Factors on Tourism Satisfaction in Lake Kenyir, Terengganu
}

\author{
Emisham Embong, Mutia Sobihah Abdul Halim, Mohamad \\ Muhaymein Ahmed Zawawi
}

Faculty of Business and Management, Universiti Sultan Zainal Abidin, Gong Badak Campus, Kuala Nerus, Terengganu, Malaysia.

\begin{abstract}
Malaysia is a country that has many unique attractions. The richness of culture and heritage as a result of this combination of variation of communities is what attracts domestic tourists to visit places of interest in Malaysia. Lake Kenyir is one prime example of an eco-tourism destination in Malaysia and has been selected as the location of this study due to the rapid development carried out by the government and the private sector in Lake Kenyir to attract tourists. Data were analysed using IBM-SPSS test. This study uses quantitative methods so that the questionnaires can include a large number of respondents, through sample selection using systematic sampling methods. Although there are empirical studies that have been conducted on such topics, but it is still limited in Terengganu in particular and Lake Kenyir in general. This study aims to examine the factors that influence tourist satisfaction with tourism in Lake Kenyir. Factor analysis was performed on 19 Destination Image variables to identify and categorize sub-factor items according to key factors such as history, culture and facilities, nature and events, activities and shopping. The Kaiser-Meyer-Olkin (KMO) value indicates a value of 0.893 and this value is suitable for factor analysis as the value is more than 0.5 . Factor analysis was used to identify correlations between factors. Factors with high correlation are placed in the same category according to priority. The results show that the combination of high-correlated factors is placed in the top position based on the eigenvalue position. The results of this study can help the government and the private sector, entrepreneurs and tourism industry players in identifying Lake Kenyir Destination Images that give overall satisfaction to Lake Kenyir tourists.
\end{abstract}

Keywords: Factor Analysis, Destination Image Index (DII), Destination Image, Push and Pull Motivation, Tourist Satisfaction, Loyalty, Lake Kenyir, Terengganu

\section{Introduction}

Malaysia is a country that has many unique attractions. This is where a combination of different races and religions can be seen where the Malays, Chinese, Indians and other races can live together in peace and harmony. The richness of culture and heritage as a result of this combination of communities is the main attraction for foreign and domestic tourists to visit Malaysia. 
With various forms of tourism landscape, abundance of nature, synergies between cultural heritage, food, arts and crafts, Malaysia is now placed as one of the must-visit world tourist destinations. The Malaysian government emphasizes the tourism sector as this sector is a major contributor to Malaysia's revenue.

Tourism Malaysia has presented the performance of Domestic Tourism for 2018. The number of domestic tourists showed a positive double digit growth of $10 \%$ in 2018 by recording a total of 78.2 million domestic tourists compared to 70.5 million domestic tourists in 2017. The number of domestic tourists coming to Terengganu decreased in 2018 is 3.87 million people compared to the year 2017 is 3.90 million people.

The main destinations for domestic tourism to Terengganu in 2018 are Dungun, Batu Buruk Beach, Besut, Kedai Payang Central Market and Kuala Terengganu. Lake Kenyir has never been listed as the main destination of domestic tourism to Terengganu from 2014 until 2018. Similarly, the Destination Image as a lake is not listed as the main destination of domestic tourism in Malaysia from 2014 until 2018. The main Destination Image listed is Beach, Island, Market, Shopping Center, Water Park and others. This study aims to examine the factors of Destination Image, Push and Pull Motivation, Overall Tourist Satisfaction and Loyalty. Although the scope of the study location selected is in Lake Kenyir, Terengganu Malaysia is one of the eco-tourism destinations in Malaysia that does not reflect the entire destination in Malaysia. However, the results of this study can be used as a basis for research and contribute to new theories in the field of tourism. The study of Destination Image is important in determining the correct image or emblem that has great potential to attract tourists to visit Malaysia. Bigne et al (2001) stated that the Destination Image is generally accepted as the overall perception of the individual or the total perception of a place. Kozak (2000) in his study identified the determining factors to tourist satisfaction among British and German tourists. Among these factors include service, local transport, cleanliness, customer service, facilities, price level, spoken language and airplane service. The conclusion is that British tourism is more easily satisfied than German tourism groups. This means that the same facilities will also create a difference of satisfaction among tourists. Customer retention is important to support sustainable growth in the industry and contribute to the country's economic growth.

Recognizing the great potential in the tourism industry identified as one of the National Key Economic Areas in the Government Transformation Program to achieve the vision of the country 2020 to make Malaysia a developed country by 2020, PEMANDU (2012). The Ministry of Tourism, Arts and Culture has also set 30 million tourist arrivals to Malaysia in conjunction with the Visit Malaysia 2020 (VM2020) campaign. This target will also achieve revenue of RM100 billion in the country's tourism industry. The huge income in the tourism industry encourages companies in the tourism industry to grow their business to make a big profit every year. Similarly, the government assisted by the local authority always ensures that tourist places are clean and have adequate infrastructure to attract tourists while maintaining the beautiful natural treasures in Malaysia. The Department of Statistics Malaysia (2014) defines Domestic Visitors as residents or those residing in Malaysia for at least one year including expatriates and non-citizens, who travel outside the environment usually for less than a year for business, leisure or personal matters other than to be employed at the place visited. Domestic visitors are categorized as follows: - Domestic tourists refer to those who travel within Malaysia for at least one night (24 hours). In 2018, Malaysia's domestic tourism reached a higher record for the number of visitor arrivals and tourism spending. A total of 221.3 million domestic visitors were recorded in 2018 with a growth of 7.7 percent compared to the previous year (8.5\%). 


\section{Research Methodology Data Collection}

In this study, two sources of data collection were used. First, before doing research in the field, researchers did some library research to provide an understanding of the research problems, concepts and theories used by previous researchers about tourism and tourist satisfaction. To obtain primary data, the researcher distributed questionnaires in the field in September 2016 with domestic tourist respondents.

\section{Sampling Method}

This study uses systematic sampling. The system also requires a list of all possible tourists to choose from. The selection of tourists is made by selecting each sample from the list (where $k$ is: a list of tourists, samples required). Example of calculation method: List of tourists $=100$ people, Sample required $=20$ people, then, $k=5$. For example, if the number 3 is selected, then the next number is $3+5=8$ (and the next number is $8+5,13+5$, etc.). The number of respondents for this Pilot study is 100 people. This number is sufficient because according to Cooper and Schindler (2011), the appropriate number of respondents is between 25 to 100 people. Johanson and Brooks (2010) suggested that the minimum number is 30 people. The data collector selected for this study was the Boat House driver. During the data collection process, data collectors help explain research objectives and, disseminate questionnaires to groups of tourists who purchase Boat House packages. Usually this packages are for 2 days and 1 night or 3 days and 2 nights. Boat House Drivers distribute questionnaires on the first day and collect questionnaires that have been answered by tourists on the last day of the trip. In the second stage, systematic probability sampling techniques were used in the study questions to increase the random sample of the study. Systematic probability sampling is a statistical method that involves the selection of each element from the sampling frame. Each group of tourists was given a number in the list handled by the Boat House driver. Tourists with odd numbers were selected for this survey. Self-administered questionnaires were submitted and collected by Boat House drivers from designated travel agencies to Researchers.

Table 1 shows the value of Cronbach's Alpha coefficient based on the overall questionnaires (likert scale) with 100 respondents found that the value of Cronbach's Alpha coefficient obtained was 0.971 . This value indicates the high validity and reliability in the study that is the value of Cronbach's Alpha at the level of $\alpha>0.6$.

Table 1: The value of Cronbach's Alpha

\begin{tabular}{|c|c|c|c|}
\hline \multicolumn{4}{|l|}{ Reliability Statistics } \\
\hline Cronbach's Alpha & $\mathrm{N}$ of Items & $\mathrm{N}$ of Respondent & Percentage \\
\hline .971 & 94 & 100 & $100 \%$ \\
\hline
\end{tabular}

Source: Field Study 2016

\section{Study Instruments}

This research instrument is in the form of a questionnaires. The questionnaires was written in Malay Language because the categories of respondents only domestic tourists. This questionnaires uses a likert scale to find out the Destination Image of Lake Kenyir. The highest likert score value reflects a positive level of perception while the low likert score value reflects a negative level of perception. Respondents are required to answer these 10 likert scale 
options. The choice of likert scale 10 was chosen to prevent respondents from being neutral or having no opinion. Table 2 shows the likert scores and rankings for sections $C, E$ and $F$.

Table 2: Scores and ratings / ratings of section C

\begin{tabular}{llllllllll}
\hline 1 & 2 & 3 & 4 & 5 & 6 & 7 & 8 & 9 & 10 \\
\hline
\end{tabular}

Strongly Disagree Strongly Agree

The research instrument used in this study is using a questionnaires. The questionnaires is a set of questions that requires the respondent to answer. These questions are divided into closed questions. Closed questions require the respondent to choose the answer given.

Table 3: Cronbach's Alpha coefficient research instrument and value of pilot study results

\begin{tabular}{|c|l|c|c|c|c|}
\hline Part & Instrument Content & Total & \multicolumn{3}{|c|}{ Realibilty Statistics } \\
\hline & & & N of Item & $\begin{array}{c}\text { N of } \\
\text { Respondent }\end{array}$ & $\begin{array}{c}\text { Cronbach's } \\
\text { Alpha }\end{array}$ \\
\hline Part A & Screening Question & 1 & & & \\
\hline Part B & Respondent Profile & 8 & & & \\
\hline Part C & Destination Image & 19 & 19 & 100 & .923 \\
\hline Part D & Satisfaction & 5 & & & \\
\hline Part E & Pull motivation & 35 & 35 & 100 & .944 \\
\hline Part F & Push Motivation & 40 & 40 & 100 & .964 \\
\hline Part G & Loyalty & 6 & & & \\
\hline Total & & 105 & 94 & 100 & .974 \\
\hline
\end{tabular}

Source: Process and Construct by Researcher

\section{Field Study}

A pilot study was conducted on a small scale before the actual study was conducted. This study was conducted to see the feasibility or reasonableness of the study to be conducted. A total of 100 respondents were selected for a pilot study consisting of domestic tourists. The pilot test data can be analysed using Cronbach's Alpha. Cronbach's Alpha Coefficient aims to ensure the validity and reliability of the constructed questions. If an item with an Alpha value less than $\alpha>0.6$ is removed from the study tool because it has low reliability. The survey in this study contains seven sections as shown in Table 3 as well as the value of Cronbach's Alpha coefficient for sections $C, D$ and $E$ as well as overall for the pilot study.

After conducting interviews with 100 respondents. The results of the study were analysed using Cronbach's Alpha coefficient to ensure validity and reliability. The results of the analysis of the analytical factors for the whole study recorded $\alpha>0.6$. This value indicates that all 19 variables in the analysis factor have high validity and reliability as in Table 4. 
Table 4: Cronbach's Alpha Coefficient Analysis Factor Analysis

\begin{tabular}{|l|l|r|}
\hline No & Dimension (factor) & $\begin{array}{r}\text { Cronbach's } \\
\text { Alpha }(\alpha)\end{array}$ \\
\hline Factor1 & History, Culture and Facilities & .927 \\
\hline 1 & Beautiful scenery and natural attraction & \\
2 & Cultural Attraction & \\
3 & Accommodation & \\
4 & Local cuisine, food and drink at restaurant & \\
5 & Personnel safety and security & \\
6 & Cleanliness & \\
7 & Local Infrastructure & \\
8 & Interesting, friendly and hospitable people & \\
9 & Various water sport activities & \\
10 & Interesting historical & \\
11 & Good night life and entertainment & \\
12 & Beautiful Gagau mountain & \\
13 & Anglers heaven & \\
\hline Factor 2 & Nature & \\
\hline 1 & Climate \& weather & \\
2 & Protected and unpolluted environment & \\
3 & Attractive rural landscape & \\
4 & Tropical Rainforest & \\
\hline Factor 3 & Event, Activities and Shopping & \\
\hline 1 & Sport facilities and activities & \\
2 & Shopping facilities & \\
\hline
\end{tabular}

Source: Field Study 2016

Data collected and coded and analysed using the Statistics Package for Social Science (SPSS) program. Factor analysis is used to identify, reduce, and organize a large number of questionnaires items into interrelated features, Piaw (2009, 2011, 2012). Relevant items will not be taken into account and analysed using this approach. Before performing the factor analysis of suitability testing the use of this method should be done. The suitability of this test is based on the correlativity of the correlation matrix detected through the Kaiser-MeyerOlkin (KMO), Piaw (2008). Based on Table 5, the KMO value is 0.893 and this is suitable for factor analysis because the KMO value exceeds 0.5, CY Piaw (2009). In addition, Bartlett's Test of Sphericity value of 1630.16 and (sig. $=.000$ ) i.e. $p<.05$ is appropriate and allows factor analysis to be performed.

Table 5: KMO Values and Bartlett Test

\begin{tabular}{|l|l|r|}
\hline \multicolumn{2}{|c|}{ KMO and Bartlett's Test } \\
\hline Kaiser-Meyer-Olkin Measure of Sampling Adequacy. & .893 \\
\hline \multirow{2}{*}{ Bartlett's Test of Sphericity } & Approx. Chi-Square & 1630.169 \\
\cline { 2 - 3 } & df & 171 \\
\cline { 2 - 3 } & Sig. & .000 \\
\hline
\end{tabular}

Source: Field Study 2016 
To find the value of the image factor of the researcher's destination, mean analysis we used. Based on the mean analysis, the Destination Image Index (DII) as a formula is used to know the Destination Image Index. According to Alegre and Garau (2009) the use of distance values 1 to 100 to facilitate the overall discussion because the higher the DII value then the more strongly agree the Destination Image level and vice versa that if the DII value is low then the Destination Image level also strongly disagree.

$$
\text { DII }=99\left[\frac{\mathrm{S}-\mathrm{MIN}}{\mathrm{MAX}-\mathrm{MIN}}\right]+1
$$

DII formula instructions:

$\mathrm{S}=$ Overall mean value

MIN = minimum value of likert scale

MAX = highest value of likert scale

Based on the above formula $S$ is the overall mean value of the Destination Image factor, which has been divided into three based on 3 Destination Image factors while MIN is the minimum value and MAX is the highest value of the variables. For the study, the questionnaires that has been scaled for the variables used is between 1 (strongly disagree) to ten (strongly agree) then this MIN is 1.00 and MAX is 10.00 . After obtaining the DII value, the DIl criteria can be determined as Table 6.

Table 6: Destination Image Criteria

\begin{tabular}{|c|c|}
\hline Value of DII & Criteria DII \\
\hline $0.81-1.00$ & Strongly Agree \\
\hline $0.66-0.80$ & Agree \\
\hline $0.51-0.65$ & Moderately Agree \\
\hline $0.35-0.50$ & Disagree \\
\hline $0.00-0.34$ & Strongly Disagree \\
\hline
\end{tabular}

Destination Image Factor Analysis of Lake Kenyir, Terengganu.

Figure 1 is a Factor Analysis Procedure in this study. Appropriate items will be retained under the categories based on previous studies and less appropriate items will be removed. A total of 19 factors were used to evaluate the Destination Image based on the Destination Image model and previous studies. Based on the results of factor analysis all 19 items were maintained and categorized into 3 factors. The factors are as follows:

i. Factor 1 - History, Culture and Facilities

ii. Factor 2 - Nature

iii. Factor 3 - Events, Activities and Shopping

Table 7 shows the full results for the 19 variables that have been categorized into three main factors. Based on the cumulative variance value of $72.63 \%$ and the eigenvalue value of more than 1.0 is very suitable for factor analysis. 
Figure 1: Factor Analysis Procedure

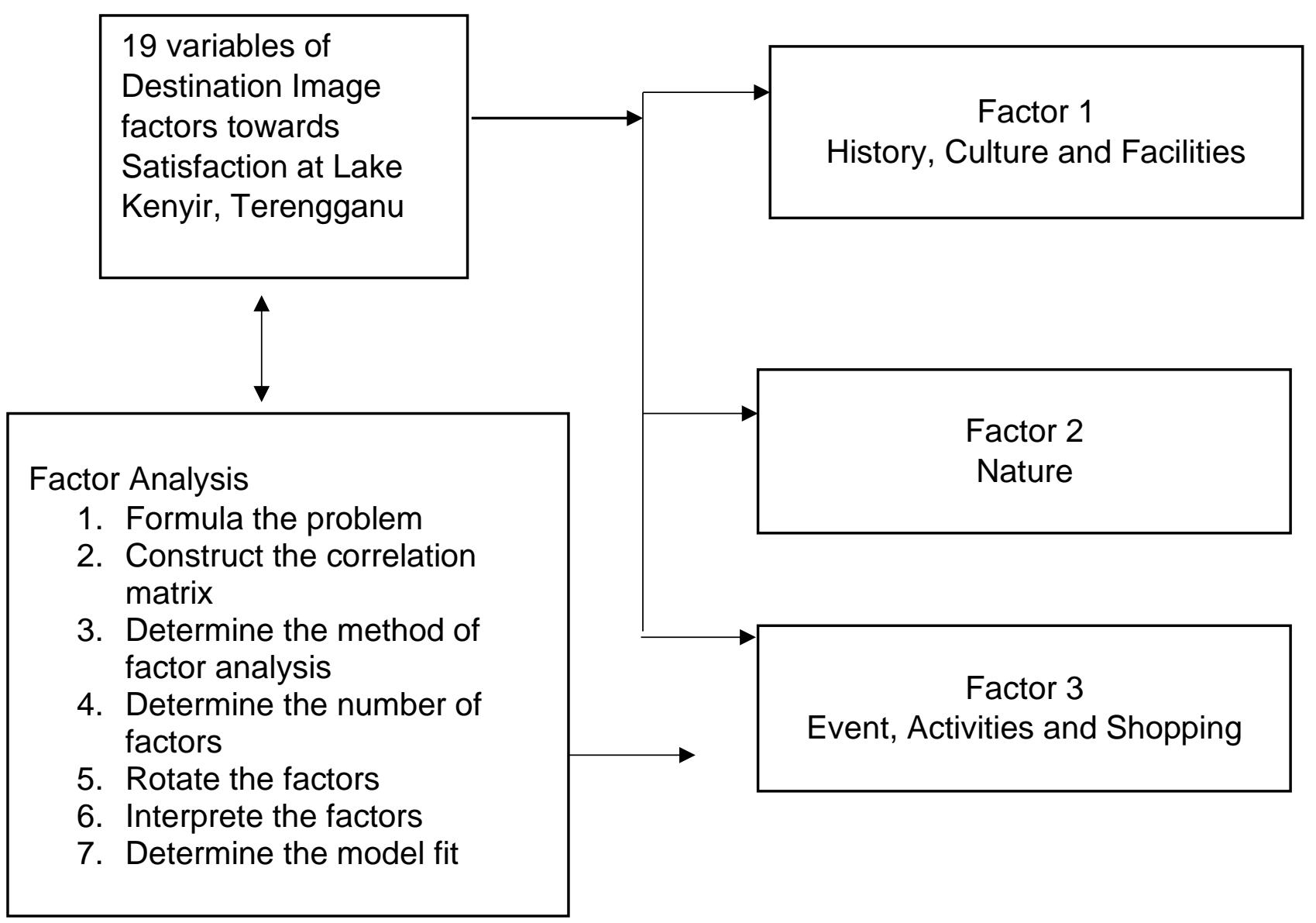

Source: Field Study 2016 
Table 7: Result of the 19 variables

\begin{tabular}{|c|c|c|c|c|c|}
\hline No & Dimension (factor) & $\begin{array}{l}\text { Factor } \\
\text { Loading }\end{array}$ & $\begin{array}{l}\text { Variant } \\
(\%)\end{array}$ & $\begin{array}{l}\text { Cumulative } \\
\text { Variant (\%) }\end{array}$ & Eigenvalue \\
\hline Factor 1 & $\begin{array}{l}\text { History, Culture and } \\
\text { Facilities }(\alpha=0.927)\end{array}$ & & 43.743 & 43.743 & 8.311 \\
\hline 1 & $\begin{array}{l}\text { Beautiful scenery and } \\
\text { natural attraction. }\end{array}$ & .588 & & & \\
\hline 2 & Cultural Attraction & .780 & & & \\
\hline 3 & Accommodation & .721 & & & \\
\hline 4 & $\begin{array}{l}\text { Local cuisine, food and } \\
\text { drink at restaurant }\end{array}$ & .659 & & & \\
\hline 5 & $\begin{array}{l}\text { Personnel safety and } \\
\text { security }\end{array}$ & .826 & & & \\
\hline 6 & Cleanliness & .774 & & & \\
\hline 7 & Local Infrastructure & .850 & & & \\
\hline 8 & $\begin{array}{l}\text { Interesting, friendly and } \\
\text { hospitable people }\end{array}$ & .755 & & & \\
\hline 9 & $\begin{array}{l}\text { Various water sport } \\
\text { activities }\end{array}$ & .719 & & & \\
\hline 10 & Interesting historical & .823 & & & \\
\hline 11 & $\begin{array}{l}\text { Good night life and } \\
\text { entertainment }\end{array}$ & .648 & & & \\
\hline 12 & Beautiful Gagau mountain & .699 & & & \\
\hline 13 & Anglers heaven & .496 & & & \\
\hline Factor 2 & Nature $(\alpha=0.837)$ & & 20.786 & 64.529 & 3.949 \\
\hline 1 & Climate \& weather & .593 & & & \\
\hline 2 & $\begin{array}{l}\text { Protected and unpolluted } \\
\text { environment }\end{array}$ & .688 & & & \\
\hline 3 & Attractive rural landscape & .519 & & & \\
\hline 4 & Tropical Rainforest & .720 & & & \\
\hline Factor 3 & $\begin{array}{l}\text { Event, Activities and } \\
\text { Shopping }(\alpha=0.779)\end{array}$ & & 8.107 & 72.637 & 1.54 \\
\hline 1 & $\begin{array}{l}\text { Sport facilities and } \\
\text { activities }\end{array}$ & .677 & & & \\
\hline 2 & Shopping facilities & .582 & & & \\
\hline
\end{tabular}

Source: Study Field 2016 
Table 8: Mean for the Destination Image

\begin{tabular}{|l|l|r|r|l|}
\hline No & Dimension (factor) & Mean & $\begin{array}{l}\text { Standard } \\
\text { Deviation }\end{array}$ & Ranking \\
\hline 1 & Beautiful scenery and natural attraction & 8.8000 & 1.94884 & 1 \\
\hline 2 & Anglers heaven & 8.2900 & 1.88184 & 2 \\
\hline 3 & Various water sport activities & 8.1000 & 2.26747 & 3 \\
\hline 4 & Beautiful Gagau Mountain & 7.0000 & 2.20193 & 4 \\
\hline 5 & Local Infrastructure & 6.8800 & 1.99129 & 5 \\
\hline 6 & $\begin{array}{l}\text { Interesting, friendly and hospitable } \\
\text { people }\end{array}$ & 6.8300 & 2.43732 & 6 \\
\hline 7 & Cleanliness & 6.7500 & 2.19906 & 7 \\
\hline 8 & Personnel safety and security & 6.6200 & 2.63918 & 8 \\
\hline 9 & Cultural Attraction & 6.4300 & 2.96190 & 9 \\
\hline 10 & Interesting historical & 6.3400 & 3.16617 & 10 \\
\hline 11 & Local cuisine, food and drink at & 5.8600 & 2.88157 & 11 \\
\hline 12 & Acstaurant & 5.5900 & 3.42921 & 12 \\
\hline 13 & Good night life and entertainment & 4.6400 & 3.01350 & 13 \\
\hline 14 & Tropical Rainforest & 8.7600 & 1.85385 & 1 \\
\hline 15 & Protected and unspoiled environment & 8.1900 & 2.13530 & 2 \\
\hline 16 & Attractive rural landscape & 7.6600 & 2.14250 & 3 \\
\hline 17 & Climate \& weather & 7.6400 & 1.82308 & 4 \\
\hline 18 & Sport facilities and activities & 6.2400 & 2.63282 & 1 \\
\hline 19 & Shopping facilities & 4.2500 & 2.87228 & 2 \\
\hline
\end{tabular}

Source : Field Study 2016

Table 8 shows the mean values and standard deviations in detail based on the satisfaction sub-factor. A total of 19 variables were used and were categorized based on analytical factors. The position of sub-factors in these factors was arranged based on the mean value.

Factors Affecting Destination Images

Table 9 shows the mean values and standard deviation for the Destination Image. Based on the mean analysis of the Lake Kenyir Destination Image, found that the Destination Image on average is between 4.2500 to 8.8000 . Based on the results of this study, Lake Kenyir Destination Image is based on the highest mean average position that is higher the average mean position more strongly agree Lake Kenyir Destination Image, and vice versa that is if the average mean low Destination Image also strongly disagree. According to the priority and average mean position, tourists increasingly agree with the first average mean position which is Nature which obtained an average mean of 8.062, the second position History, Culture and Facilities which obtained an average mean value of 6.779 , the third position is Events, Activities and Shopping which obtained an average mean value of 5.245. Based on the results of this study, respondents strongly agree with Nature, and is the main attraction of respondents to visit Lake Kenyir. According to Inskeep et. al., (1996) there are three main types of tourist attractions to a tourist destination, namely natural attractions based on the characteristics of the natural environment, cultural attractions based on human activities and 
special attractions created artificially. All three attractions show images of tourist destinations. Lake Kenyir has Natural attractions such as tropical rainforests, protected and unspoiled environments, Attractive rural landscapes and good weather and climate throughout the year.

Table 9: Mean Values and Standard Deviation

\begin{tabular}{|l|c|c|c|}
\hline Lake Kenyir Image Destination Factors & $\begin{array}{c}\text { Means } \\
\text { Values }\end{array}$ & $\begin{array}{c}\text { Standard } \\
\text { Deviation }\end{array}$ & Ranking \\
\hline Nature & 8.062 & 1.988 & 1 \\
\hline History, Culture and Facilities & 6.779 & 2.539 & 2 \\
\hline Event, Activities and Shopping & 5.245 & 2.752 & 3 \\
\hline Average Total Means Overall & 6.695 & & \\
\hline
\end{tabular}

Source: Field Study 2016

Kenyir Lake Destination Image Index (DII)

This average analysis is used to ensure that the index value obtained can reflect the Destination Image in Lake Kenyir. To obtain the Destiny Image Index (DII) has been used as the formula below.

$$
\text { DII }=99-\left[\frac{S-M I N}{M A X-M I N}\right]+1
$$

Based on the above formula $S$ is the mean value of overall satisfaction i.e. Nature, History, Culture and Facilities, and Events, Activities and Shopping which have been divided into three based on 3 Destination Image factors while MIN is the minimum value and MAX is the highest value of the variable. For the study, the questionnaires that has been scaled for the variables used is between 1 (strongly disagree) to ten (strongly agree) then this MIN is 1.00 and MAX is 10.00 .

$$
\text { DII } \left.=63.64=99-\frac{6.6951-1}{10.0-1.0}\right]+1
$$

The index value obtained for the Lake Kenyir Destination Image is $63.64 \%$ which is based on a scale distance of 0 to 100 and this index value shows that the DII in Lake Kenyir is at a moderately agreeable level as in Table 10, Sukardi and Chandrawatisma (2006). 
Table 10: Criteria Destination Image

\begin{tabular}{|c|c|}
\hline Value of DII & Criteria DII \\
\hline $0.81-1.00$ & Strongly Agree \\
\hline $0.66-0.80$ & Agree \\
\hline $0.51-0.65$ & Moderately Agree \\
\hline $0.35-0.50$ & Disagree \\
\hline $0.00-0.34$ & Strongly Disagree \\
\hline
\end{tabular}

Source: Sukardi and C.Chandrawatisma (2006)

Overall, tourists agreed with the Destination Image in Lake Kenyir, Terengganu but at a moderate level agree because the value is worth more than 50\%, Alegre and Garau (2009). The higher the value of the Destination Image Index (DII), the higher the level of agreement between tourists and DII Lake Kenyir.

Assessment of Overall Satisfaction of Tourists as in Table 11. The majority give an assessment on a scale of 6 which is 21 people or $21 \%$ of Tourists.

Vacations that provide an interesting and adequate experience for Tourists, the majority give an assessment on a scale of 10 which is 23 people or $23 \%$ of Tourists. Majority of tourist are strongly agree with the statement.

Local Authority provides tourism products and services that suit the needs of tourists, the majority give an assessment on a scale of 6 which is 22 people or $22 \%$ of tourists.

Lake Kenyir has all the facilities needed for tourist to carry out tourism activities. The majority give ratings on a scale of 6 and 8 that is 15 people and 15 people or $15 \%$ and $15 \%$ of Tourists Accommodation facilities at Lake Kenyir are very satisfactory. The majority of tourists give a rating on a scale of 1 which is 18 people or $18 \%$ of tourists. Majority of tourist are strongly disagree with the statement. 
Table 11: Overall assessment of tourism in Lake Kenyir

\begin{tabular}{|c|c|c|c|}
\hline Overall Satisfaction & $\begin{array}{l}\text { Level of } \\
\text { assessment }\end{array}$ & $\begin{array}{c}\mathrm{N}=\mathrm{No}, \text { of } \\
\text { Respondent }\end{array}$ & $\begin{array}{c}\text { Percentage } \\
(\%)\end{array}$ \\
\hline $\begin{array}{l}\text { Assessment of Overall } \\
\text { Satisfaction of Tourists }\end{array}$ & $\begin{array}{c}1 \\
2 \\
3 \\
4 \\
5 \\
6 \\
7 \\
8 \\
9 \\
10 \\
\text { Total }\end{array}$ & $\begin{array}{c}1 \\
0 \\
0 \\
6 \\
13 \\
21 \\
12 \\
18 \\
18 \\
11 \\
100\end{array}$ & $\begin{array}{c}1.0 \\
0.0 \\
0.0 \\
6.0 \\
13.0 \\
21.0 \\
12.0 \\
18.0 \\
18.0 \\
11.0 \\
100.0\end{array}$ \\
\hline $\begin{array}{l}\text { Vacations that provide an } \\
\text { interesting and adequate } \\
\text { experience for Tourists }\end{array}$ & $\begin{array}{c}1 \\
2 \\
3 \\
4 \\
5 \\
6 \\
7 \\
8 \\
9 \\
10 \\
\text { Total }\end{array}$ & $\begin{array}{c}1 \\
3 \\
6 \\
1 \\
9 \\
22 \\
5 \\
12 \\
18 \\
23 \\
100\end{array}$ & $\begin{array}{c}1.0 \\
3.0 \\
6.0 \\
1.0 \\
9.0 \\
22.0 \\
5.0 \\
12.0 \\
18.0 \\
23.0 \\
100.0\end{array}$ \\
\hline $\begin{array}{l}\text { Local Authority provides } \\
\text { tourism products and services } \\
\text { that suit the needs of tourists }\end{array}$ & $\begin{array}{c}1 \\
2 \\
3 \\
4 \\
5 \\
6 \\
7 \\
8 \\
9 \\
10 \\
\text { Total } \\
\end{array}$ & $\begin{array}{c}1 \\
1 \\
5 \\
5 \\
12 \\
22 \\
13 \\
10 \\
21 \\
10 \\
100 \\
\end{array}$ & $\begin{array}{c}1.0 \\
1.0 \\
5.0 \\
5.0 \\
12.0 \\
22.0 \\
13.0 \\
10.0 \\
21.0 \\
10.0 \\
100.0 \\
\end{array}$ \\
\hline $\begin{array}{l}\text { Lake Kenyir has all the facilities } \\
\text { needed for tourist to carry out } \\
\text { tourism activities }\end{array}$ & $\begin{array}{c}1 \\
2 \\
3 \\
4 \\
5 \\
6 \\
7 \\
8 \\
9 \\
10 \\
\text { Total }\end{array}$ & $\begin{array}{c}0 \\
1 \\
9 \\
6 \\
14 \\
15 \\
14 \\
15 \\
13 \\
13 \\
100\end{array}$ & $\begin{array}{c}0.0 \\
1.0 \\
9.0 \\
6.0 \\
14.0 \\
15.0 \\
14.0 \\
15.0 \\
13.0 \\
13.0 \\
100.0\end{array}$ \\
\hline
\end{tabular}




\begin{tabular}{|lc|c|c|c|}
\hline Accommodation & facilities at & 1 & 18 & 18.0 \\
Lake Kenyir & are very & 2 & 9 & 9.0 \\
satisfactory & & 3 & 8 & 8.0 \\
& & 4 & 5 & 5.0 \\
& 5 & 5 & 5.0 \\
& 6 & 14 & 14.0 \\
& 7 & 6 & 6.0 \\
& 8 & 10 & 10.0 \\
& 9 & 14 & 14.0 \\
& 10 & 11 & 11.0 \\
& & 100 & 100.0 \\
\hline
\end{tabular}

Level of Assesesment as per below

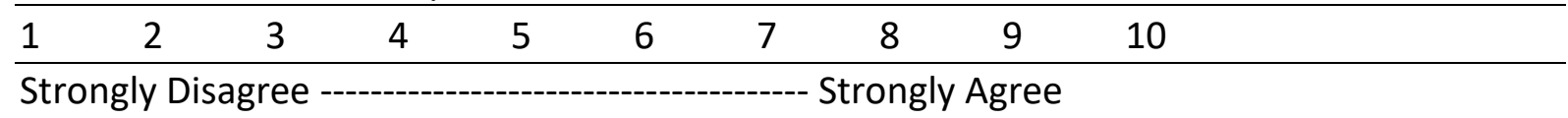

\section{Conclusion}

Based on the mean analysis of the main factors that influence the Destination Image is Nature followed by History, Culture and Facilities and lastly Events, Activities and Shopping.

Factor analysis was performed on 19 variables to identify and categorize sub-factor for items according to key factors such as History, Culture and Facilities, Nature and Events, Activities and Shopping. The Kaiser-Meyer Olkin (KMO) value indicates a value of 0.893 and this value is suitable for factor analysis as the value is more than 0.5 . Factor analysis was used to identify correlations between factors. Factors with high correlation are placed in the same category according to priority. The results show that the combination of high-correlated factors is placed in the top position based on the eigenvalue position.

These three factors show a high cumulative variance value of $72.63 \%$ and a large eigenvalue of more than 1.0. Cronbach's Alpha values were also high at $\alpha>0.6$ and significantly 0.000 . The higher the value of eigenvalue then placed in factor 1 , then factor 2 , and factor 3 . The results of factor analysis found that factor 1 is the history, culture and facilities that get the value of eigenvalue which is 8.311 and the value of $\alpha=0.927$. Factor 2 is that Nature has an eigenvalue value of 3.949 and a value of $\alpha=0.837$. Factor 3 is Events, Activities and Shopping which has an eigenvalue value of 1.54 and $\alpha$ value $=0.779$.

After conducting the factor analysis method and categorizing the sub-factors into the main factors, mean analysis was done to answer the objective of the first study which is the factor influencing the Destination Image in Lake Kenyir. Based on the mean value found that Nature is in the first position and is a factor of Destination Image in Lake Kenyir which obtained a mean average value of 8.062 , the second position recorded a mean average value of 6.779 , namely History, culture and facilities, the third position recorded a mean average value of 5.245 namely Events, Activities and Shopping.

The image of the destination will influence the decision of the tourists in choosing the destination. A clear and positive image is very important for a destination to develop as a superior tourist destination, Mohamed and Nordin (2007). Based on the image of the destination, tourists will make a visit to the destination and will meet the expectations of the tourist destination as well as see the value and quality of tourism in the destination and will indirectly give satisfaction to tourists, Wang et. al (2009). To obtain the value of the Destination Image Index, the Destination Image Index (DII) formula was used. The value of DII 
obtained is $63.64 \%$. This value indicates that tourists agree with the Destination Image on Lake Kenyir but at a moderate level. Based on the scale distance from 0 to 100 . Overall tourists agree with the image of the destination in Lake Kenyir but at a moderate level or at the level of "satisfactory" because the value is worth more than $50 \%$, Joaquin and Garau Jaume (2009).

\section{References}

Amran, N. (2014). Domestic Tourism Survey Report, Malaysia 2014. Malaysia: Department of Statistics, Malaysia.

Ahmad, Idris, N. F. M., Jusoh, H., Ramli, Z., Sum, S. M., A Buang, A., Jalil, N. H. A., Sahazali, N. (2014) Analisis faktor kepuasan pelancong terhadap tarikan pelancongan warisan di Melaka. Geografia OnlineTM Malaysia, Journal of Society and Space 10 issue 8 (72-86) 72

Alegre, J., \& Garau, J. (2010) Tourist satisfaction indices. A critical approach, Investigaciones Regionales ISSN: 1695-7253

Bigne, J. E., Sanchez, M. I., \& Sanchez, J. (2001). Tourism image, evaluation variables and after purchase behaviour: Inter-relationship. Tourism Management, 22(6), 607-616.

Cooper, D. R., \& Schindler, P. S. (2011). Business research methods (11th ed.). New York: McGraw-Hill/Irwin.

Inskeep, E., Abd, N., Hassan, C. E. C. (1996) Perancangan pelancongan: Pendekatan pembangunan bersepadu dan berkekalan. Dewan Bahasa dan Pustaka, Kuala Lumpur.

Johanson, G. A., \& Brooks, G. P. (2010) Initial scale development: sample size for pilot studies. Educational and psychological measurement. 70(3):394-400. doi:10.1177/0013164409355692

Kozak, M. (2002). Comparative analysis of tourist motivations by nationality and destinations. Tourism management, 23(3), 221-232.

Mohamed, B., \& Nordin, N. (2007) Perancangan pelancongan. Dewan Bahasa dan Pustaka, Kuala Lumpur.

Piaw, C. Y. (2008) Kaedah dan statistik penyelidikan buku 3. Asas statistik penyelidikan analisis data skala ordinal dan skala nominal. Mc Graw Hill, Kuala Lumpur.

Piaw, C. Y. (2009) Kaedah dan statistik penyelidikan buku 5. Statistik penyelidikan lanjutan ujian univariat dan multivariat. Mc Graw Hill, Kuala Lumpur.

Piaw, C. Y. (2011) Kaedah dan statistik penyelidikan buku 1. Kaedah penyelidikan. Mc Graw Hill, Kuala Lumpur.

Piaw, C. Y. (2012) Kaedah dan statistik penyelidikan buku 2. Asas statistik penyelidikan. Mc Graw Hill, Kuala Lumpur.

Sukardi \& Chandrawatisma, C. (2006). Analisis tingkat kepuasan terhadap produk corned pronas Produksi Pt Cip, Denpasar Bali. Jurnal teknologi industri pertanian. No. 18 Volume 2

Wang, X., Zhang, J., Gu, C., \& Zhen, F. (2009). Examining antecedents and consequences of tourist satisfaction: a structural modelling approach. Tsinghua Science \& Technology 14(3), 397-406. 